Mr. E. R. Davies (Kodak, Ltd.). Further details of the Exhibition can be obtained from the Physical Society, 1 Lowther Gardens, Prince Consort Road, London, S.W.7.

\section{Physical Society: Spring Meeting at Bristol}

THE spring meeting of the Physical Society will be held at the H. H. Wills Physical Laboratory, Royal Fort, Bristol 8, during March 24 and 25. The meeting, which will be divided into three sessions, will be on the "Deformation Markings on Crystals and their Relation to the Mechanism of Slip". Papers from the following universities and research establishments will be presented at this meeting : University of Bristol ; University of Birmingham; Aeronautical Research Laboratory, Melbourne; University of Sheffield; University of Edinburgh; Atomic Energy Research Establishment ; and University of Chicago. Visitors wishing to attend this meeting should apply to the offices of the Physical Society, 1 Lowther Gardens, Prince Consort, Road, London, S.W.7, for further particulars.

\section{Colonial Service: Recent Appointments}

THE following appointments have recently been made in the Colonial Service: W. J. M. Irving (assistant director of agriculture, Uganda), deputy director of agriculture, Uganda; W. A. Gordon (assistant conservator of forests, Cyprus), conservator of forests, British Guiana; C. B. Bissett (deputy director, Geological Survey, Uganda), director, Geological Survey, Tanganyika; C. B. Brown (scientific assistant, Department of Agriculture, Trinidad), soil survey officer, Department of Agriculture, Trinidad; L. E. Honore (senior statistician, Mauritius), assistant director of statistics, Mauritius; F. Durocher Yvon (agricultural officer, Seychelles), director of agriculture, Seychelles; N. R. Brockington, ecologist, Northern Rhodesia; P. Brown, agricultural officer, Nyasaland; E. W. Findlay, agricultural officer, Nigeria; J. E. Y. Hardcastle, botanist, Nigeria; Miss E. Harrison, botanist, Nigeria; N. W. Smyth, agricultural officer, Sarawak ; W. Barber, geologist, Nigeria ; J. L. Early, veterinary officer, Nyasaland ; G. B. Symons, veterinary officer, Uganda; Miss J. A. K. Abel, statistical officer, Gold Coast; G. F. Bamford, assistant conservator of forests, Sierra Leone; L. C. Chapas, assistant statistician, Nigeria; J. G. Devitt, assistant conservator of forests, Northern Rhodesia ; P. Grainger, laboratory superintendent, Virus Research Institute, Lagos, Nigeria; J. M. Hotson, soil survey officer, (xold Coast ; R.F. Montgomery, soil scientist, Nigeria; D. R. Walker, meteorological officer, Nyasaland; I. Watson, statistician, Department of Agriculture, Federation of Malaya.

\section{University of Sheffield}

THE following appointments have recently been made in the University of Sheffield : R. Shepherd, senior lecturer in the Postgraduate School of Mining ; Dr. E. O. Hall, lecturer in physics ; Dr. B. A. Bilby, honorary lecturer in physical metallurgy. A separate Department of Microbiology has been established in the University, and Dr. S. R. Elsden, senior lecturer in microbiology, will be in charge, with effect from October 1 next.

\section{The Night Sky in March}

Foul moon occurs on March 11d. 18h. 14m., U.T., and new moon on March 25d. 20h. 12m. The fol- lowing conjunctions with the moon take place: March 13d. 17h., Saturn $7^{\circ}$ N.; March 16d. 08h., Mars $7^{\circ}$ N.; March 24d. 02h., Venus $2^{\circ}$ S. ; March 26d. 03h., Mercury 0.7 S.; and March 27d. 05h., Jupiter $6^{\circ} \mathrm{S}$. Mercury is an evening star, setting at $18 \mathrm{~h} .10 \mathrm{~m}$. on March 1 and at $19 \mathrm{~h} .45 \mathrm{~m}$. on March 15 and 31, and is stationary on March 26. Venus is $\mathbf{a}$ morning star, rising a little before $6 \mathrm{~h}$. until about the middle of the month, and at $5 \mathrm{~h} .15 \mathrm{~m}$. at the end of the month ; its stellar magnitude is $-3 \cdot 3$, and the visible portion of the illuminated disk varies between 0.87 and 0.93 . Mars rises at $23 \mathrm{~h}$. $35 \mathrm{~m} ., 22 \mathrm{~h} .55 \mathrm{~m}$. and $21 \mathrm{~h}$. 55m. on March 1,15 and 31 , respectively, and towards the end of the month it lies nearly in a line between $\alpha$ and $\gamma$ Libræ. Jupiter sets at $20 \mathrm{~h}$. $50 \mathrm{~m}$. and $20 \mathrm{~h} .15 \mathrm{~m}$. on March 1 and 15 , respectively, but after this it draws too close to the sun for favourable observation and at the end of the month sets only an hour after the sun. Saturn rises at $20 \mathrm{~h} .35 \mathrm{~m}$. and $18 \mathrm{~h} .25 \mathrm{~m}$. on March 1 and 31 respectively, and is visible throughout the night and morning hours, lying a little north of $\theta$ Virginis throughout the month. Occultations of stars brighter than magnitude 6 are as follows, observations being made at Greenwich : March 4 d. $18 \mathrm{~h} .59 \cdot 5 \mathrm{~m} ., 136$ Taur. $(D)$; March 29d. 20h. $30 \cdot 8 \mathrm{~m}$., $q$ Taur. $(D) . \quad D$ refers to disappearance. Vernal equinox occurs on March 20d. 16h.

\section{Announcements}

A CONGREss of the International Diabetes Federation will be held at Leyden during the second week of July. Further information can be obtained from Dr. R. D. Lawrence, 149 Harley Street, London, W.1.

THE second symposium on chemical-biological correlation, sponsored by the Chemical-Biological Coordination Center, National Research Council, will be held during October 24-25 in the auditorium of the United States National Academy of Sciences, 2101 Constitution Avenue, Washington, D.C. The subject will be the "Mechanism of Drug Action and Drug Resistance". Further details can be obtained from the Center at 2101 Constitution Avenue, Washington, D.C.

THE Chemical, Metallurgical and Mining Society of South Africa, in co-operation with the Diamond Research Laboratory, is arranging a symposium on diamond drilling, to be held in Johannesburg during April 21-23. Following the technical sessions, visits will be arranged to the gold and diamond mines of South Africa and the copper properties of Northern Rhodesia. Further details can be obtained from the Diamond Research Laboratory, P.O. Box 916, Johannesburg.

Prof. R. D. Passey, head of the Department of Experimental Pathology and Cancer Research, University of Leeds, has received the following letter from the Trustees of the Anna Fuller Fund of New Haven, Connecticut: "The Trustees of The Anna Fuller Fund, at their meeting February 8th, 1952, on their own motion, voted a gift to the amount of One Hundred Pounds to the University of Leeds, in memory of King George VI. The Trustees specifically provided that this gift needs no acknowledgement or special accounting, but may simply be used, in whole or in part, at any time or from time to time, for any purpose having to do with cancer research in your complete and unfettered discretion". It is proposed that the money should be devoted towards the cost of the electron microscope recently installed in the Department. 